\title{
The effects of ionizing radiation on the structure and antioxidative and metal binding capacity of the cell wall of microalga Chlorella sorokiniana
}

DOI:

10.1016/j.chemosphere.2020.127553

\section{Document Version}

Accepted author manuscript

Link to publication record in Manchester Research Explorer

Citation for published version (APA):

Vojvodi, S., Danilovi Lukovi, J., Zechmann, B., Jevtovi , M., Bogdanovi Pristov , J., Stani, M., Lizzul, A. M., Pittman, J., \& Spasojevi, I. (2020). The effects of ionizing radiation on the structure and antioxidative and metal binding capacity of the cell wall of microalga Chlorella sorokiniana. Chemosphere, 260, [127553].

https://doi.org/10.1016/j.chemosphere.2020.127553

\section{Published in:}

Chemosphere

\section{Citing this paper}

Please note that where the full-text provided on Manchester Research Explorer is the Author Accepted Manuscript or Proof version this may differ from the final Published version. If citing, it is advised that you check and use the publisher's definitive version.

\section{General rights}

Copyright and moral rights for the publications made accessible in the Research Explorer are retained by the authors and/or other copyright owners and it is a condition of accessing publications that users recognise and abide by the legal requirements associated with these rights.

\section{Takedown policy}

If you believe that this document breaches copyright please refer to the University of Manchester's Takedown Procedures [http://man.ac.uk/04Y6Bo] or contact uml.scholarlycommunications@manchester.ac.uk providing relevant details, so we can investigate your claim.

\section{OPEN ACCESS}


1 The effects of ionizing radiation on the structure and antioxidative and metal-

2 binding capacity of the cell wall of microalga Chlorella sorokiniana

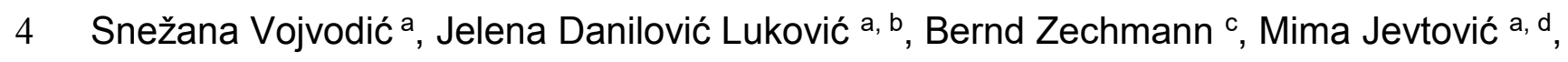
5 Jelena Bogdanović Pristov ${ }^{a}$, Marina Stanić a , Alessandro Marco Lizzul e, Jon K. Pittman

6 f, Ivan Spasojević a, *

7

8 a Department of Life Sciences, Institute for Multidisciplinary Research, University of

9 Belgrade, Kneza Višeslava 1, 11030 Belgrade, Serbia

10 b Institute for Application of Nuclear Energy, University of Belgrade, Banatska 31b,

1111080 Belgrade-Zemun, Serbia (present address)

$12{ }^{c}$ Center for Microscopy and Imaging, Baylor University, One Bear Place 97046, Waco,

$13 T X, U S A$

14 d Faculty of Chemistry, University of Belgrade, Studentski trg 12-16 11001 Belgrade,

15 Serbia (present address)

16 e Varicon Aqua, Ball Mill Top Business Park, Unit 12, Hallow, WR2 6PD, UK

$17 \mathrm{f}$ Department of Earth and Environmental Sciences, School of Natural Sciences,

18 University of Manchester, Michael Smith Building, Oxford Road, Manchester, M13 9PT,

19 UK

20

$21{ }^{*}$ Corresponding author.

22 E-mail: redoxsci@gmail.com (I. Spasojević); Tel: +381 112078459 


\section{Abstract}

25 The impact of ionizing radiation on microorganisms such as microalgae is a topic of

26 increasing importance for understanding the dynamics of aquatic ecosystems in

27 response to environmental radiation, and for the development of efficient approaches

28 for bioremediation of mining and nuclear power plants wastewaters. Currently, nothing

29 is known about the effects of ionizing radiation on the microalgal cell wall, which

30 represents the first line of defence against chemical and physical environmental

31 stresses. Using various microscopy, spectroscopy and biochemical techniques we show

32 that the unicellular alga Chlorella sorokiniana elicits a fast response to ionizing radiation.

33 Within one day after irradiation with doses of 1 to $5 \mathrm{~Gy}$, the fibrilar layer of the cell wall

34 became thicker, the fraction of uronic acids was higher, and the capacity to remove the

35 main reactive product of water radiolysis increased. In addition, the isolated cell wall

36 fraction showed significant binding capacity for $\mathrm{Cu}^{2+}, \mathrm{Mn}^{2+}$, and $\mathrm{Cr}^{3+}$. The irradiation

37 further increased the binding capacity for $\mathrm{Cu}^{2+}$, which appears to be mainly bound to

38 glucosamine moieties within a chitosan-like polymer in the outer rigid layer of the wall.

39 These results imply that the cell wall represents a dynamic structure that is involved in

40 the protective response of microalgae to ionizing radiation. It appears that microalgae

41 may exhibit a significant control of metal mobility in aquatic ecosystems via biosorption

42 by the cell wall matrix.

43

44 Keywords: Alga; Cell wall; Copper; Radiation 


\section{Introduction}

47 Microalgae are exposed to variable doses of ionizing radiation from natural (e.g. radionuclides from soil and rocks), and anthropogenic sources (radioactive waste,

49 radionuclides from mining/ores, nuclear power plant accidents and nuclear testing)

50 (UNSCEAR, 2011). Because photosynthetic microalgae are primary producers of

51 biomass and oxygen, any damaging effects of radiation on these microorganisms will

52 directly impact the function and organization of aquatic ecosystems (Fuma et al., 2012;

53 Nascimento and Bradshaw, 2016). Conversely, microalgae appear to show resilience to

54 radiation stress; for example they are very efficient in the remediation of freshwaters

55 that are contaminated with radioactive metals, such as strontium, uranium, and caesium

56 (Fukuda et al., 2014; Kalin et al., 2005; Vanhoudt et al., 2018). Furthermore, some

57 microalgal species are known to colonize spent nuclear fuel storage pools and uranium

58 tailings pounds showing high levels of radiation and heavy metals pollution (Baselga-

59 Cervera et al., 2018; MeGraw et al., 2018; Rivasseau et al., 2016). Seasonal algal

60 blooms in the spent nuclear fuel storage at Sellafield, UK, is a phenomenon that

61 probably best illustrates the potential of microalgae to adapt to radiation and to thrive in

62 such ecosystems (Foster et al., 2020; MeGraw et al., 2018). It is worth mentioning that

63 these properties demonstrate that microalgae are capable pioneer species in the

64 colonization of highly inhospitable environments (Baselga-Cervera et al., 2018;

65 Rivasseau et al., 2016). Clearly, the effects of ionizing radiation on microalgae and the 66 mechanisms of their adaptation are of fundamental environmental interest, as

67 highlighted recently by the disastrous contamination of water in the Fukushima-Daiichi 68 nuclear power plant accident (Fukuda et al., 2014). It is important to note that high 
69 energy electromagnetic radiation (such as gamma and $\mathrm{X}$ ) is the most relevant ionizing

70 radiation in aquatic systems. It has high penetrating power, and energy that is sufficient

71 to cause radiolysis of water and to directly oxidize/damage biomolecules (LaVerne, 72 2000).

73 It is known that the exposure of microalgae to radiation may result in oxidative damage

74 of lipids and DNA and decreased photosynthetic efficiency, growth and survival

75 (Boreham et al., 1993; Gomes et al., 2017; Rea et al., 2008), as well as in upregulated

76 antioxidative defence and photoprotection, alterations in carbohydrate and general

77 metabolic profile, and other traits of radioresistance (Bradshaw et al., 2019; Foster et

78 al., 2020; Golz and Bradshaw, 2019; MeGraw et al., 2018; Santier et al., 1985).

79 However, the response at the level of the cell wall has not yet been examined. The cell

80 wall is the zone of contact between the microalgal cell and the environment, and the first

81 line of chemical and physical defence (Baudelet et al., 2017). It represents a dynamic

82 multi-layer structure that is actively involved in the adaptation to different stressors

83 (Beacham et al., 2014; Jeong et al., 2017; Yap et al., 2016). Pertinent to this, the cell

84 wall is the main (radio)metal sequestrating (i.e. biosorbent) component of microalgal

85 biomass (Hadjoudja et al., 2010; Horikoshi et al., 1979; Vanhoudt et al., 2018). Finally,

86 the thickness and structure of the microalgal cell wall is of technological relevance as it

87 represents a key biological parameter for efficient lipid extraction during microalgal

88 biodiesel production (Anto et al., 2020; Yap et al., 2016). Additionally it is of great

89 relevance as a source of carbohydrates for microalgal bioethanol production

90 (Hernández et al., 2015). 
91 The aim of our study was to determine the effects of ionizing radiation (X-rays) on the

92 cell wall of Chlorella sorokiniana. We analyzed: (i) the structure of the cell wall using

93 transmission electron microscopy (TEM) and Fourier-transform infra-red spectroscopy

94 (FTIR); (ii) the capacity of cell wall isolates to remove hydroxyl radical (HO-) using

95 electron paramagnetic resonance (EPR) spin-trapping spectroscopy; and (iii) the

96 capacity of cell wall isolates to bind heavy metals using biochemical assays and EPR.

97 C. sorokiniana was selected as a widely used model microalga with high potential for

98 application in industry and wastewater treatment (Lizzul et al., 2018), as it is also

99 commonly found in many freshwater ecosystems.

100 2. Material and methods

101 2.1. Cell cultivation

102 C. sorokiniana (strain CCAP 211/8K; alternative designation UTEX 1230) was obtained

103 from the Culture Collection of Algae and Protozoa, UK. Algal inocula were added to $3 \mathrm{~N}$ -

$104 \mathrm{BBM}+\mathrm{V}$ medium; $35 \mathrm{~mL}$ in $50 \mathrm{~mL}$ Erlenmeyer flasks (TEM experiments), or $150 \mathrm{~mL}$ in

$105250 \mathrm{~mL}$ flasks (all other experiments). Initial density in all samples was $5 \times 10^{5} \mathrm{cells} / \mathrm{mL}$.

106 Algae were grown for 20 days at $22^{\circ} \mathrm{C}$ on an orbital shaker $(120 \mathrm{rpm})$ in growth cabinet

107 with a continuous photon flux of $120 \mu \mathrm{mol} \mathrm{m}^{-2} \mathrm{~s}^{-1}$ (MST TL-D Reflex $36 \mathrm{~W} 8401 \mathrm{SLV} / 25$

108 tubes, Philips, Amsterdam, Netherlands). At day 20, cultures were in the stationary

109 phase, as determined by optical density (OD 750 was $7.2 \pm 0.5)$ and biomass $(2.0 \pm 0.2$

$110 \mathrm{mg} / \mathrm{mL}$ ). The volume of samples was corrected for evaporation at day 20 with sterile

111 deionized water. Samples were irradiated and returned to the growth cabinet for

112 additional $24 \mathrm{~h}$, and then microalgae were collected for further analysis or processing.

$113 \quad$ 2.2. Irradiation protocol 
114 Aliquots of culture $(35 \mathrm{~mL})$ were placed in a Petri dish and exposed to X-ray irradiation 115 using CellRad irradiation chamber (Faxitron Bioptics LLC, Tucson, AZ, USA; tube 116 power: $750 \mathrm{~W}$; focal spot size: $1.0 \times 1.4 \mathrm{~mm}$; filtration: $1.6 \mathrm{~mm} \mathrm{Be}$ and $0.5 \mathrm{~mm} \mathrm{Al}$; beam

117 angle: $40^{\circ}$ divergence; dosimeter: ion chamber). Energy was kept constant at $120 \mathrm{kV}$; 118 doses and rates were adjusted by changing the current (the doses released by the 119 source were 10, 20 and $50 \mathrm{~Gy}$ ). Total absorbed doses were $1.09 \mathrm{~Gy}$ (rate, $0.25 \mathrm{~Gy} / \mathrm{min}$; 120 exposure time $4.4 \mathrm{~min}$ ), $2.21 \mathrm{~Gy}$ (rate, $0.25 \mathrm{~Gy} / \mathrm{min} ; 8.9 \mathrm{~min}$ ), and $5.45 \mathrm{~Gy}$ (rate, 0.55

$121 \mathrm{~Gy} / \mathrm{min} ; 9.9 \mathrm{~min})$. For simplicity, we refer to these absorbed doses as 1, 2, and 5 Gy.

122 The effects of acute irradiation on cell viability were tested using Evans Blue stain 123 (Sigma-Aldrich, St. Louis, MI, USA), as described previously (Zuppini et al., 2007).

124 Evans Blue is a commonly used measure of cell viability; non-viable cells loose cellular 125 permeability allowing accumulation of the Evans Blue dye, therefore an increased 126 proportion of Evans Blue stained cells in a population indicates an increased proportion 127 of non-vaible cells. The viability is presented as a percentage of Evans Blue negative 128 cells. At least 100 cells were analysed per sample.

129 2.3. TEM microscopy

130 Cells were spun down at $5000 \mathrm{~g}$ for $5 \mathrm{~min}$, and fixed overnight at $4^{\circ} \mathrm{C}$ in $0.1 \mathrm{M}$ 131 phosphate buffer (PB; pH 7.2) containing $3 \%(\mathrm{v} / \mathrm{v})$ glutaraldehyde and $1 \%(\mathrm{v} / \mathrm{v})$ 132 paraformalaldehyde (Serva, Heidelberg, Germany). Post-fixation was performed with $1331 \%(\mathrm{w} / \mathrm{v})$ osmium tetroxide (Serva) in PB for $2 \mathrm{~h}$ at room temperature. Samples were 134 dehydrated in a graded acetone series and then embedded in resin for soft blocks 135 (AGR1031, Agar Scientific, Stansted, UK). Ultra-thin sections $(70 \mu \mathrm{m})$, obtained with a 136 Leica UC7 ultramicrotome (Leica Microsystems, Wetzlar, Germany), were stained for 15 
137 minutes with $1 \%$ uranyl acetate and 5 minutes with $3 \%$ lead citrate and observed at 60

$138 \mathrm{kV}$ in a JEOL JEM-1010 TEM (Jeol, Tokyo, Japan). The thickness of cell wall layers

139 was measured using Image $(\mathrm{NIH})$. At least 25 cells with the nuclear mid-section from

140 the control and each irradiation dose treatment were analysed. The thickness of cell

141 wall layers was measured at four points (on the $\mathrm{x}$ and $\mathrm{y}$ axis of the micrograph with 0

142 point at the cell's centre).

143 2.4. Cell wall isolation

144 Biomass from $150 \mathrm{~mL}$ samples (untreated and irradiated with different doses) was spun 145 down and washed $2 \times$ in $5 \mathrm{~mL}$ distilled water by centrifugation at $2300 \mathrm{~g} / 5 \mathrm{~min}$. Cell wall 146 isolation was conducted according to the previously described protocol with slight 147 modification (Simonović et al., 2011). Protocol steps were performed at room 148 temperature if not indicated otherwise: (i) homogenization in mortar with liquid $\mathrm{N}_{2}$ and 149 collection of the sample ( $\sim 0.5 \mathrm{~g}$ fresh weight) with $5 \mathrm{~mL}$ water; (ii) $2 \times$ wash with $5 \mathrm{~mL}$ 150 water by centrifugation at $800 \mathrm{~g} / 5 \mathrm{~min}$; (ii) $10 \times$ shake (15 min) and wash ( $800 \mathrm{~g} / 5$ $151 \mathrm{~min}$ ) with $5 \mathrm{~mL}$ of chloroform:methanol (1/1 v/v) mixture; (iii) Overnight incubation in the 152 chloroform:methanol solution at $4^{\circ} \mathrm{C}$; (iv) shake $(1 \mathrm{~h})$ and wash $(800 \mathrm{~g} / 5 \mathrm{~min})$ in $5 \mathrm{~mL} 1$ $153 \mathrm{M} \mathrm{NaCl}$; (iv) shake $(1 \mathrm{~h})$ in $5 \mathrm{~mL} 0.5 \%$ Triton and $5 \times$ wash $(800 \mathrm{~g} / 5 \mathrm{~min})$ with $5 \mathrm{~mL}$ 154 water; (v) shake (20 min) and wash ( $800 \mathrm{~g} / 5 \mathrm{~min})$ in $5 \mathrm{~mL}$ methanol; (vi) $4 \times$ shake (20 $155 \mathrm{~min}$ ) and wash (800 g / $5 \mathrm{~min}$ ) in $5 \mathrm{~mL}$ acetone; (vii) dry overnight at $30^{\circ} \mathrm{C}$; (viii) $2 \times$ 156 incubation with $5000 \mathrm{U}$ of amylase (Megazyme, Wicklow, Ireland) per $1 \mathrm{~g}$ of sample in 157 PB ( $\mathrm{pH} 7.2)$ for $24 \mathrm{~h}$ at $30^{\circ} \mathrm{C}$ to remove starch. (ix) wash with $5 \mathrm{~mL}$ PB several times 158 until supernatant becomes clear; ( $x$ ) $2 \times$ shake $(20 \mathrm{~min})$ and wash ( $800 \mathrm{~g} / 5 \mathrm{~min})$ with 5 $159 \mathrm{~mL}$ acetone, and leave to dry. The protocol was aimed at preserving the structure of all 
160 cell wall polymers (Chen et al., 2000; Hall and Moore, 1983). Gravimetry of isolated cell

161 wall and fresh weight of samples was performed. The composition of the isolated cell

162 wall was analysed by mid-infrared FTIR $\left(4000-400 \mathrm{~cm}^{-1}\right)$ using a Nicolet 6700

163 spectrometer (Thermo Scientific, Waltham, MA, USA). The resolution of spectra was 1

$164 \mathrm{~cm}^{-1}$.

\section{2.5. Metal-binding capacity}

166 Cell wall isolates were tested for capacity to bind $\mathrm{Cu}^{2+}, \mathrm{Mn}^{2+}$, and $\mathrm{Cr}^{3+}$ ions. Isolates $(0.5$

$167 \mathrm{mg}$ ) were placed into $2 \mathrm{~mL}$ of $5 \mathrm{mM}$ solutions of $\mathrm{CuCl}_{2}, \mathrm{MnCl}_{2}$, or $\mathrm{KCr}\left(\mathrm{SO}_{4}\right)_{2}$ (Sigma-

168 Aldrich), that were prepared in $20 \mathrm{mM}$ Hepes buffer ( $\mathrm{pH}$ 7.5). Samples were vigorously

169 shaken for $10 \mathrm{~min}$ in polypropylene tubes (Eppendorf, Hamburg, Germany), and

170 centrifuged at $13000 \mathrm{~g} / 10 \mathrm{~min}$. Supernatant was collected for biochemical assays,

171 whereas pellet was collected for EPR spectroscopy. The concentration of $\mathrm{Cu}^{2+}$ in the

172 supernatant was determined using the fluorescent probe Fura-2 (Sigma-Aldrich), as

173 described previously (McCall and Fierke, 2000), on a FluoroLog 3 fluorimeter (Horiba,

174 Kyoto, Japan) with excitation at $340 \mathrm{~nm}$ and emission at $510 \mathrm{~nm}$. Concentrations of two

175 other metals were determined according to previously described colorimetric assays:

$176 \mathrm{Mn}^{2+}$ with formaldoxime reagent at $\lambda=450 \mathrm{~nm}$ (Goto et al., 1962), and $\mathrm{Cr}^{3+}$ with xylenol

177 orange at $\lambda=530 \mathrm{~nm}$ (Cheng, 1967). Working solutions for calibration curves were

178 prepared daily by stepwise dilution from standard stock solution. Samples were diluted

179 prior to measurements to match the calibration range. The decrease in the

180 concentration of metals in the buffer was used to calculate the binding capacity ( $\mathrm{\mu g}$ of

181 bound metal per $\mathrm{mg}$ of cell wall isolate).

182 2.6. Antioxidative capacity of the cell wall 
183 The capacity of isolated cell wall $(0.5 \mathrm{mg}$ in $50 \mu \mathrm{L}$ water sample) to scavenge $\mathrm{HO}$

184 radical was established using the Fenton reaction, a $\mathrm{HO}$-generating system: $\mathrm{Fe}^{2+}(1$

$185 \mathrm{mM}$; Sigma-Aldrich) $+\mathrm{H}_{2} \mathrm{O}_{2}(3 \mathrm{mM}$; Carlo Erba Reagents, Milano, Italy), and an EPR

186 spin-trapping method with DEPMPO spin-trap (5-diethoxyphosphoryl-5-methyl-1-

187 pyrroline-N-oxide; Santa Cruz Biotechnologies, Dallas, TX, USA) at the final

188 concentration of $5 \mathrm{mM}$. Deionized ultrapure $18 \mathrm{M} \Omega$ water was used in all experiments.

189 The $\mathrm{pH}$ of samples was 6.5. Spectra were recorded after 2 min incubation at room

190 temperature, using Bruker EMX Nano X-band $(9.65 \mathrm{GHz})$ spectrometer with the

191 following settings: power attenuation, $25 \mathrm{~dB}$; modulation amplitude, $0.2 \mathrm{mT}$; modulation

192 frequency, $100 \mathrm{kHz}$; sweep time, 2 min. Antioxidative capacity to remove HO was

193 calculated using the amplitude (A) of DEPMPO/OH signals according to the following

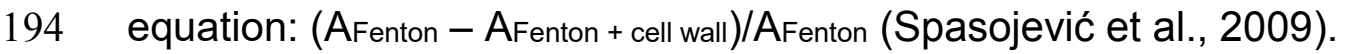

195 2.7. EPR spectroscopy of transition metals

196 Collected pellets (cell wall isolates with bound metals) were placed into $100 \mu \mathrm{L}$ of Hepes

197 buffer. Samples were vortexed, placed into quartz tubes, and snap-frozen in liquid $\mathrm{N}_{2}$.

198 Measurements were performed at $77 \mathrm{~K}$ on a Bruker EMX Nano spectrometer with finger

199 dewar with liquid $\mathrm{N}_{2}$, using the following settings: power attenuation, $25 \mathrm{~dB}$; modulation

200 amplitude, $0.8 \mathrm{mT}$; modulation frequency, $100 \mathrm{kHz}$; sweep time, $1 \mathrm{~min}$; number of

201 scans/accumulations, 10. Spectra of $\mathrm{Cu}^{2+}, \mathrm{Mn}^{2+}$ and $\mathrm{Cr}^{3+}(1.5 \mathrm{mM})$ in Hepes buffer were

202 recorded for comparison as blanks. Spectrum of $\mathrm{Cu}^{2+}(1.5 \mathrm{mM})$ in the presence of

203 chitosan $(10 \mathrm{mM})$ was recorded to analyse interactions with cell wall. Spectral

204 simulations were performed to establish $g$-values and hyperfine splitting $(A)$, using

205 Hyperfine Spectrum Software (WF Hagen, TU Delft, The Netherlands) (Hagen, 2008). 
207 All experiments were performed in three biological replicates, except for the viability test

208 (four replicates) and cell wall isolation (five replicates). Results are presented as mean \pm

209 standard error (SE) where appropriate. Statistical significance $(p<0.05)$ in comparison

210 to control experiments was calculated using Mann-Whitney $U$ test.

\section{3. Results}

212 TEM micrographs illustrate the structure of the C. sorokiniana cell wall, which is

213 composed of a trilaminar sheath (TLS) and fibrilar wall (Fig. 1a). TLS appears as a

214 translucent line inserted between two electron dense lines; the outer layer (mature

215 mother wall) is separated by an electron translucent space from the thin inner layer

216 (daughter wall). The fibrilar wall is located between the TLS and plasma membrane

217 (Baudelet et al., 2017). The established thickness of the cell wall in untreated C.

218 sorokiniana is in accordance with data published in the past (Martinez et al., 1991).

219 Irradiation did not induce significant changes in the TLS. On the other hand, the

220 thickness of the fibrilar wall was significantly increased one day after irradiation with 1

221 and 2 Gy (Fig. 1b). In line with this observation, the yield of cell wall was increased by

$222 \sim 50 \%$ in irradiated microalgae (Fig. 1c). The slight change in the fibrilar wall following 5

223 Gy of irradiation was not statistically significant. It is noteworthy that there were no 224 significant changes to cell viability in response to irradiation: $90.8 \pm 0.7 \%$ in controls;

$22584.1 \pm 4.1 \%$ for algae exposed to $1 \mathrm{~Gy} ; 74.7 \pm 1.4 \%$ for $2 \mathrm{~Gy}$; and $75.4 \pm 1.1 \%$ for $5 \mathrm{~Gy}$.

226 Cell wall thickness is an important biological and technological parameter. It provides

227 chemical (including antioxidative) and mechanical protection from the surroundings, 228 determines the carbon budget of the cell, and affects the extractability of lipids and 
229 pigments as well as other industrially-relevant properties of microalgal biomass (Anto et 230 al., 2020; Baudelet et al., 2017; Jeong et al., 2017). The thickening of the cell wall

231 appears to be a common response of microalgae to other types of environmental stress,

232 such as $\mathrm{N}$-deficiency and changes in salinity (in marine algae), under different growing

233 conditions (Beacham et al., 2014; Jeong et al., 2017; Yap et al., 2016). In accord with

234 our findings, the exposure of Nannochloropsis to $\mathrm{N}$-stress has been reported to result in

235 the thickening of the inner cellulose-based sheath of a bilayer cell wall (Jeong et al., 236 2017).

237 We applied FTIR spectroscopy to analyze the effects of radiation on cell wall 238 composition. FTIR spectra of cell wall isolates showed strong absorption peaks at 3290, $2392940,1645,1535,1446,1385,1237,1147$, and $1055 \mathrm{~cm}^{-1}$ (Fig. 2). The assignation was

240 performed according to available FTIR spectra of microalgal biomass, which mainly

241 reflect the functional groups in the cell wall (Dmytryk et al., 2014; Driver et al., 2015;

242 Hadjoudja et al., 2010; Petrovič and Simonič, 2016). The cell wall composition of $C$.

243 sorokiniana is not fully known. However, available data imply that Chlorella cell wall is 244 composed of: (i) a "rigid wall" (sheaths in TLS), which contains glucosamine and $\mathrm{N}$ 245 acetylglucosamine in the form of a chitosan-like polymer; and (ii) a plastic polymeric 246 matrix (fibrilar wall), which is composed of rhamnose, galactose, uronic acids 247 (glucuronic acid in C. sorokiniana), arabinose, mannose, and other sugars (Baudelet et 248 al., 2017; Russell, 1995). The band at $3290 \mathrm{~cm}^{-1}$ was assigned to glucosamine (N-H 249 stretching), and neutral sugars (O-H and $\mathrm{C}-\mathrm{O}$ stretching). Bands at 1645, 1535 and $2501055 \mathrm{~cm}^{-1}$ mainly come from chitosan-like polysaccharides. The $1055 \mathrm{~cm}^{-1}$ band was 251 weaker in irradiated samples, which may come from oxidation-induced breakage of 
252 polymeric chains (Wasikiewicz et al., 2005). On the other hand, the bands derived from 253 carboxyl and carbonyl groups were stronger in cell wall isolated from irradiated

254 microalgae. This implies that $C$. sorokiniana accumulates uronic acids in the fibrilar wall 255 in response to ionizing radiation. It is noteworthy that no bands corresponding to either 256 phosphoryl or sulfone groups were detected, which is in line with available data on cell 257 wall composition in Chlorella (Baudelet et al., 2017). Next we examined the impact of 258 irradiation on the capacity of the cell wall to scavenge $\mathrm{HO}$, the main oxidizing species 259 produced in water radiolysis (LaVerne, 2000). The exposure of C. sorokiniana to 260 radiation led to significant increase of antioxidative capacity of the cell wall (Fig. 3). Of 261 note, less intensive spectra stand for more antioxidative capacity. It has been proposed 262 previously that plants 'rely' on non-enzymatic antioxidative defence against $\mathrm{HO}$, such 263 as carbohydrates and cell wall polymers (Bogdanović Pristov et al., 2011; Spasojević et 264 al., 2009). There is no enzymatic system for the removal of this radical. The increased 265 antioxidative capacity could be explained by a higher fraction of uronic acids in the cell 266 wall of irradiated microalgae. A number of studies have found that uronic acid-rich 267 macromolecules, such as xylan (glucuronic acid) and pectin (galacturonic acid), are 268 highly susceptible to reactions with radicals, including HO (Akhlaq et al., 1990; Fry, 269 1998; Zegota, 2002). We have shown in a comparative study of antioxidative activities 270 of plant cell wall components that pectin and xylan are the most efficient $\mathrm{HO}$ 271 scavengers (Bogdanović Pristov et al., 2011). Alternatively, higher antioxidative capacity 272 may be related to radiation-induced fragmentation of chitosan-like polymer. Several 273 studies have reported that such fragmentation results in improved antioxidative 274 performance (Abd El-Rehim et al., 2012; Chmielewski, 2010; Feng et al., 2008; Muley et 
275 al., 2019), which has been related to increased solubility of chitosan fragments 276 compared to high molecular weight polymer (Chmielewski, 2010). The observed 277 increase in cell wall mass and antioxidative capacity represents a fast adaptation 278 mechanism which may explain previous observations that microalgae are less sensitive 279 to chronic than to acute exposure to ionizing radiation (Fuma et al., 2012). Cell wall 280 isolates showed substantial capacity to bind heavy metals (Fig. 4): $\mathrm{Cu}^{2+}, 0.48 \mathrm{mg} / \mathrm{mg}$; $281 \mathrm{Mn}^{2+}, 0.38 \mathrm{mg} / \mathrm{mg}$; and $\mathrm{Cr}^{3+}, 0.33 \mathrm{mg} / \mathrm{mg}$ of cell wall isolate (values for control 282 samples). The irradiation of $C$. sorokiniana culture provoked a significant increase in the 283 capacity of the cell wall to bind $\mathrm{Cu}^{2+}$ (Fig. 4a), whereas the capacities for $\mathrm{Mn}^{2+}$ and $\mathrm{Cr}^{3+}$ 284 binding remained unaltered (Fig. 4b, c). To the best of our knowledge, this is the first 285 report on the metal binding capacity of isolated microalgal cell wall polymers. There are 286 a number of reports of metal binding capacities of intact microalgal biomass (Mehta and 287 Gaur, 2005; Wilde and Benemann, 1993), which were lower than reported in this study. 288 For example, the capacity of Chlorella vulgaris biomass for $\mathrm{Cu}^{2+}$ binding ranged from 2890.01 to $0.19 \mathrm{mg} / \mathrm{mg}$ in previous studies (Mehta and Gaur, 2005). Our results are in line 290 with reports identifying cell wall as the main biosorption component of microalgal 291 biomass (Horikoshi et al., 1979; Klimmek et al., 2001; Mehta and Gaur, 2005; Wilde and 292 Benemann, 1993). Further, higher affinity for $\mathrm{Cu}^{2+}$ than $\mathrm{Mn}^{2+}$ and $\mathrm{Cr}^{3+}$ is probably 293 related to differences in coordinative chemistry of these metals. According to the 294 principle of hard and soft acids and bases (HSAB), $\mathrm{Cu}^{2+}$ is a borderline acid, whereas $295 \mathrm{Mn}^{2+}$ and $\mathrm{Cr}^{3+}$ are hard acids (Hancock and Martell, 1996). This means that they prefer 296 different types of ligands/binding sites within the cell wall. The improvement of $\mathrm{Cu}^{2+}$ 297 binding capacity by irradiation may be important for adaptation of microalgae to extreme 
298 conditions. Radiological contamination of aquatic ecosystems is usually accompanied 299 by metal pollutants including copper, and vice versa copper mining wastewaters 300 typically show increased levels of radiation (Dessouki et al., 2005; Fuma et al., 2012). 301 Finally, microalgal biomass has been used as biosorbent for remediation of mining, 302 industrial and radioactive wastewaters (Bradshaw et al., 2019; Dessouki et al., 2005;

303 Kaplan, 2013). Our results imply that the application of microalgae in biosorbent 304 technology could be improved by using isolated cell wall material as a sorbent rather 305 than intact cells. However, commercial side of biomass processing has to be evaluated 306 and taken into account.

307 All of the applied metals are paramagnetic so their coordination could be analysed using 308 low-T EPR spectroscopy (Hagen, 2008). Fig. 5 compares EPR spectra of $\mathrm{Cu}^{2+}$ in the 309 buffer, bound to cell wall isolates, and bound to chitosan. $\mathrm{Cu}^{2+}(S=1 / 2)$ showed EPR 310 signal with one strong $g$ line and four weak lines coming from hyperfine coupling with $311{ }^{63} \mathrm{Cu} /{ }^{65} \mathrm{Cu}$ nuclei $(I=3 / 2)$ along $g_{\|}$. Spectral shape and the rank order of $g$-values $\left(g_{\|}>\right.$

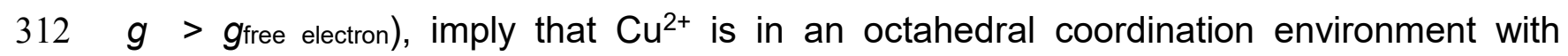
313 tetragonal distortion in all analyzed systems (Garribba and Micera, 2006). However, 314 hyperfine splittings $(A \|)$ and $g \|$ values imply different nature of $\mathrm{Cu}^{2+}$ ligands (Peisach and 315 Blumberg, 1974). In the buffer, $\mathrm{Cu}^{2+}$ spectrum showed $g_{\|}=2.31$ and $A_{\|}=14.7 \mathrm{mT}$ (Fig. 316 5a), which are characteristic for $\mathrm{Cu}^{2+}$ bound to 30 and $1 \mathrm{~N}$ ligands, and in accord with a 317 previous study on $\mathrm{Cu}^{2+}$ coordination with Hepes and $\mathrm{OH}^{-}$ions (Sokołowska and Bal, 318 2005). On the other hand, the spectrum of $\mathrm{Cu}^{2+}$ that is bound to the isolated cell wall 319 showed $g_{\|}=2.22$ and $A_{\|}=19.0 \mathrm{mT}$. These values imply that $\mathrm{Cu}^{2+}$ is bound to $3 \mathrm{~N}$ and 32010 , or to $4 \mathrm{~N}$ ligands (Fig. $5 \mathrm{~b}$ ). This implies that glucosamine moieties represent the 
321 main sites of coordinate bonding of $\mathrm{Cu}^{2+}$ to the cell wall. This is further substantiated by

322 similar $g_{\|}$and $A_{\|}$values for $\mathrm{Cu}^{2+}$ that is bound to chitosan-like polymer, which is

323 composed of glucosamine and $\mathrm{N}$-acetylglucosamine (Fig. 5c). Our findings are in line

324 with a previous study that identified amine, secondary amide and carboxyl groups as

325 the most important for $\mathrm{Cu}^{2+}$ binding to the surface of Spirulina cells (Dmytryk et al.,

326 2014). Amine groups in an electron-withdrawing system (such as glucosamine), as well

327 as secondary amides represent borderline bases and match $\mathrm{Cu}^{2+}$ according to HSAB

328 principle (Hancock and Martell, 1996). It is important to point out that spectra did not

329 change notably for the cell wall that was isolated from irradiated algae (Fig. 5b). From

330 these data we can speculate that the increase in $\mathrm{Cu}^{2+}$ binding capacity may be the

331 result of increased accessibility to $\mathrm{N}$ ligands in damaged/loosened chitosan-like

332 structure in TLS. Pertinent to this, increased binding capacity for uranium in heated

333 biomass of Chlorella has been attributed to cell wall denaturation and increased

334 accessibility of binding sites (Horikoshi et al., 1979).

335 Fig. 6a shows a characteristic six-line spectrum of $\operatorname{Mn}^{2+}(S=5 / 2, I=5 / 2)$ in solution.

336 Cell wall isolates with $\mathrm{Mn}^{2+}$ showed similar spectra but of lower intensity (Fig. 6b), which

337 implies that $\mathrm{Mn}^{2+}$ was released from the cell wall into the buffer. The remaining bound

$338 \mathrm{Mn}^{2+}$ did not show detectable EPR signal. The main reason for this is zero field splitting

339 anisotropy that is promoted by the loss of rapid molecular tumbling, in combination with

340 a large number of transitions, i.e. complex multiline spectrum (Ignjatović et al., 2012;

341 Sigel and Sigel, 2000). Empirically, sufficient $\mathrm{S} / \mathrm{N}$ ratio for the signal of bound $\mathrm{Mn}^{2+}$ is

342 achieved when concentration of $\mathrm{Mn}^{2+}$ in solution is $10-50$-fold lower than bound $\mathrm{Mn}^{2+}$

343 (Sigel and Sigel, 2000), which was not the case here. The EPR results imply that $\mathrm{Mn}^{2+}$ 
344 is weakly bound to the cell wall and that irradiation did not alter $\mathrm{Mn}^{2+}$ binding capacity, in

345 accordance with the biochemical measurements. Next, $\mathrm{Cr}^{3+}(S=3 / 2)$ has two nuclear

346 spins: $I=0$ (natural abundance of $83 \%$ ), and $I=3 / 2(9.5 \%)$ (Azamat et al., 2013). This

347 results in an EPR spectrum containing one strong line for the first isotope, and four

348 weak lines for the latter (Fig. 6c). Similarly to $\mathrm{Mn}^{2+}$, the binding $\mathrm{Of}^{\mathrm{Cr}^{3+}}$ to large slowly-

349 tumbling molecules results in significant line broadening due to zero field splitting

350 anisotropy and fast relaxation (Andriessen and Groenewege, 1976; Hagen, 2008). Line

351 broadening could be also related to paramagnetic effects, i.e. dipolar interactions

352 between $\mathrm{Cr}^{3+}$ ions that are closely positioned within cell wall matrix (Hagen, 2008;

353 Padlyak et al., 2000). Therefore, no resolved EPR spectrum was obtained for $\mathrm{Cr}^{3+}$ that

354 was bound to cell wall (Fig. $6 \mathrm{~d}$ ). The lack of signal of $\mathrm{Cr}^{3+}$ in solution means that $\mathrm{Cr}^{3+}$ is

355 more strongly bound to the cell wall than $\mathrm{Mn}^{2+}$. This may be related to stronger

356 electrostatic interactions with negative charges on the cell wall for more positive $\mathrm{Cr}^{3+}$.

\section{4. Conclusions}

358 In summary, our results demonstrate that the microalgal cell wall is a dynamic and

359 stress-responsive structure that is involved in fast adaptation to environmental

360 challenges. Within a day after exposure to ionizing radiation, C. sorokiniana

361 strengthened its first line of defence against the external environment. The wall became

362 thicker and showed altered composition with increased fraction of uronic acids in the

363 fibrilar layer. The cell wall showed improved capacity to remove the main reactive

364 product of water radiolysis. In addition, the isolated microalgal cell wall exhibited high

365 copper binding capacity, which was further increased by irradiation. These fast

366 adaptation mechanisms are most likely part of a complex process of responses to 
367 different stressors. Knowledge of these responses is essential for the understanding of 368 the ecotoxicology of ionizing radiation and the application of microalgae in metal 369 remediation, wastewater treatment, and biosorbent industry.

370

371 Acknowledgment

372 This work is supported by The NATO Science for Peace and Security Programme, 373 Project number G5320.

374 


\section{References}

376 Abd El-Rehim, H.A., El-Sawy, N.M., Hegazy, S.A., Soliman, S.A., Elbarbary, A.M.,

377 2012. Improvement of antioxidant activity of chitosan by chemical treatment and ionizing

378 radiation. Int. J. Biol. Macromol. 50, 403-413.

379 Akhlaq, M.S., Schuchmann, H.P., Von Sonntag, C., 1990. Degradation of the 380 polysaccharide alginic acid: a comparison of the effects of UV light and ozone. Environ.

381 Sci. Technol. 24, 379-383.

382 Andriessen, W.T.M., Groenewege, M.P., 1976. Electron paramagnetic resonance of 383 chromium(III) complexes of the type cis- $[\mathrm{Cr}(2,2$ '-bpy $) 2 \mathrm{XY}] \mathrm{Z}$, cis- $[\mathrm{Cr}(\mathrm{I}, \mathrm{IO}-\mathrm{phen}) 2 \mathrm{XY}] \mathrm{Z}$,

384 and cis- [Cr(ox)2XY]Z in frozen solutions and powders. Inorg. Chem. 15, 621-625.

385 Anto, S., Mukherjee, S.S., Muthappa, R., Mathimani, T., Deviram, G., Kumar, S.S.,

386 Verma, T.N., Pugazhendhi, A., 2020. Algae as green energy reserve: Technological

387 outlook on biofuel production. Chemosphere 242, 125079.

388 Azamat, D.V., Dejneka, A., Lančok, J., Trepakov, V.A., Jastrabi, L., Badalayan, A.G., 389 2013. Pulse-electron paramagnetic resonance of $\mathrm{Cr}^{3+}$ centers in $\mathrm{SrTiO}_{3}$. J. Appl. Phys. $390113,174-186$.

391 Baselga-Cervera, B., Romero-López, J., García-Balboa, C., Costas, E., López-Rodas, 392 V., 2018. Improvement of the uranium sequestration ability of a Chlamydomonas sp. 393 (ChISP strain) isolated from extreme uranium mine tailings through selection for 394 potential bioremediation application. Front. Microbiol. 9, 523.

395 Baudelet, P., Ricochon, G., Linder, M., Muniglia, L., 2017. A new insight into cell walls 396 of Chlorophyta. Algal Res. 25, 333-371. 
397 Beacham, T.A., Bradley, C., White, D.A., Bond, P., Ali, S.T., 2014. Lipid productivity 398 and cell wall ultrastructure of six strains of Nannochloropsis: Implications for biofuel 399 production and downstream processing. Algal Res. 6, 64-69.

400 Bogdanović Pristov, J., Mitrović, A., Spasojević, I., 2011. A comparative study of 401 antioxidative activities of cell-wall polysaccharides. Carbohydr. Res. 346, 2255-2259.

402 Boreham, D.R., Mitchel, R.E.J., 1993. DNA repair in Chlamydomonas reinhardtii 403 induced by heat shock and gamma radiation. Radiat. Res. 135, 365-371.

404 Bradshaw, C., Meseh, D.A., Alasawi, H., Qiang, M., Snoeijs-Leijonmalm, P., 405 Nascimento, F.J.A., 2019. Joint effects of gamma radiation and cadmium on 406 subcellular-, individual- and population-level endpoints of the green microalga 407 Raphidocelis subcapitata. Aquat. Toxicol. 211, 217-226.

408 Chen, M., Sommer, A.J., McClure, J.W., 2000. Fourier transform-IR determination of 409 protein contamination in thioglycolic acid lignin from radish seedlings and improved 410 methods for extractive-free cell wall preparation. Phytochem. Anal. 11, 153-159.

411 Cheng, K.L., 1967. Spectrophotometric determination of chromium with xylenol orange 412 and methylthymol blue. Talanta 14, 875-877.

413 Chmielewski, A.G., 2010. Chitosan and radiation chemistry. Radiat. Phys. Chem. 79, $414 \quad 272-275$.

415 Dessouki, T.C.E., Hudson, J.J., Neal, B.R., Bogard, M.J., 2005. The effects of 416 phosphorus additions on the sedimentation of contaminants in a uranium mine pit-lake.

417 Water Res. 39, 3055-3061.

418 Dmytryk, A., Saeid, A., Chojnacka, K., 2014. Biosorption of microelements by Spirulina: 419 towards technology of mineral feed supplements. Sci. World. J. 2014, 356328. 
420 Driver, T., Bajhaiya, A.K., Allwood, J.W., Goodacre, R., Pittman, J.K., Dean, A.P., 2015.

421 Metabolic responses of eukaryotic microalgae to environmental stress limit the ability of

422 FT-IR spectroscopy for species identification. Algal Res. 11, 148-155.

423 Feng, T., Du, Y., Li, J., Hu, Y., Kennedy, J.F., 2008. Enhancement of antioxidant activity

424 of chitosan by irradiation. Carbohyd. Polym. 73, 126-132.

425 Foster, L., Muhamadali, H,, Boothman, C., Sigee, D., Pittman, J.K., Goodacre, R.,

426 Morris, K., Lloyd, J.R., 2020. Radiation tolerance of Pseudanabaena catenata, a

427 cyanobacterium relevant to the First Generation Magnox Storage Pond. Front.

428 Microbiol. 11, 515.

429 Fry, S.C., 1998. Oxidative scission of plant cell wall polysaccharides by ascorbate430 induced hydroxyl radicals. Biochem. J. 332, 507-515.

431 Fukuda, S.Y., Iwamoto, K., Atsumi, M., Yokoyama, A., Nakayama, T., Ishida, K.,

432 Inouye, I., Shiraiwa, Y., 2014. Global searches for microalgae and aquatic plants that 433 can eliminate radioactive cesium, iodine and strontium from the radio-polluted aquatic 434 environment: a bioremediation strategy. J. Plant. Res. 127, 79-89.

435 Fuma, S., Kawaguchi, I., Kubota, Y., Yoshida, S., Kawabata, Z., Polikarpov, G.G., 2012.

436 Effects of chronic $y$-irradiation on the aquatic microbial microcosm: equi-dosimetric 437 comparison with effects of heavy metals. J. Environ. Radioact. 104, 81-86.

438 Garribba, E., Micera, G., 2006. The determination of the geometry of $\mathrm{Cu}(\mathrm{II})$ complexes, 439 J. Chem. Educ. 83, 1229-1232.

440 Golz, A.L., Bradshaw, C., 2019. Gamma radiation induced changes in the biochemical 441 composition of aquatic primary producers and their effect on grazers. Front. Environ. 442 Sci. 7, 100. 
443 Gomes, T., Xie, L., Brede, D., Lind, O.C., Solhaug, K.A., Salbu, B., Tollefsen, K.E., 444 2017. Sensitivity of the green algae Chlamydomonas reinhardtii to gamma radiation:

445 Photosynthetic performance and ROS formation. Aquat. Toxicol. 183, 1-10.

446 Goto, K., Komatsu, T., Furukawa, T., 1962. Rapid colorimetric determination of 447 manganese in waters containing iron: A modification of the formaldoxime method. Anal. 448 Chim. Acta 27, 331-334.

449 Hadjoudja, S., Deluchat, V., Baudu, M., 2010. Cell surface characterisation of 450 Microcystis aeruginosa and Chlorella vulgaris. J. Colloid Interface Sci. 342, 293-299.

451 Hagen, W.R., 2008. Biomolecular EPR Spectroscopy. CRC Press, Boca Raton.

452 Hall, J.L., Moore, A.L., 1983. Isolation of Membranes and Organelles from Plant Cells. 453 Academic Press, Cambridge.

454 Hancock, R.D., Martell, A.E., 1996. Hard and soft acid-base behavior in aqueous 455 solution. J. Chem. Educ. 73, 654-661.

456 Hernández, D., Riaño, B., Coca, M., García-González, M.C., 2015. Saccharification of 457 carbohydrates in microalgal biomass by physical, chemical and enzymatic pre458 treatments as a previous step for bioethanol production. Chem. Eng. J. 262, 939-945.

459 Horikoshi, T,, Nakajima, A., Sakaguchi, T., 1979. Uptake of uranium by various cell 460 fractions of Chlorella regularis. Radioisotopes 28, 485-488.

461 Ignjatović, A., Stević, Z., Lavrnić, D., Nikolić-Kokić, A., Blagojević, D., Spasić, M., 462 Spasojević, I., 2012. Inappropriately chelated iron in the cerebrospinal fluid of 463 amyotrophic lateral sclerosis patients. Amyotroph. Lateral. Scler. 13, 357-362. 
464 Jeong, S.W., Nam S.W., Hwangbo, K., Jeong, W.J., Jeong, B.R., Chang, Y.K., Park, 465 Y.I., 2017. Transcriptional regulation of cellulose biosynthesis during the early phase of 466 nitrogen deprivation in Nannochloropsis salina. Sci. Rep. 7, 5264.

467 Kalin, M., Wheeler, W.N., Meinrath, G., 2005. The removal of uranium from mining 468 waste water using algal/microbial biomass. J. Environ. Radioact. 78, 151-77.

469 Kaplan, D., 2013. Absorption and adsorption of heavy metals by microalgae, in: 470 Richmond, A., Hu, Q. (Eds), Handbook of Microalgal Culture: Applied Phycology and 471 Biotechnology. John Wiley \& Sons Ltd, Hoboken.

472 Klimmek, S., Stan, H.J., Wilke, A., Bunke, G., Buchholz, R., 2001. Comparative analysis 473 of the biosorption of cadmium, lead, nickel, and zinc by algae. Environ. Sci. Technol. 35, $474 \quad 4283-4288$.

475 LaVerne, J.A., 2000. $\mathrm{OH}$ radicals and oxidizing products in the gamma radiolysis of 476 water. Radiat. Res. 153, 196-200.

477 Lizzul, A.M., Lekuona-Amundarain, A., Purton, S., Campos, L.C., 2018. 478 Characterization of Chlorella sorokiniana, UTEX 1230. Biology 7, E25.

479 Martinez, F., Ascaso, C., Orus, M.I., 1991. Morphometric and stereologic analysis of 480 Chlorella vulgaris under heterotrophic growth conditions. Ann. Bot. 67, 239-245.

481 McCall, K.A., Fierke, C.A., 2000. Colorimetric and fluorimetric assays to quantitate 482 micromolar concentrations of transition metals. Anal. Biochem. 284, 307-315.

483 MeGraw, V.E., Brown, A.R., Boothman, C., Goodacre, R., Morris, K., Sigee, D., 484 Anderson, L., Lloyd, J.R., 2018. A novel adaptation mechanism underpinning algal 485 colonization of a nuclear fuel storage pond. mBio 9, e02395-e02417. 
486 Mehta, S.K., Gaur, J.P., 2005. Use of algae for removing heavy metal ions from 487 wastewater: progress and prospects. Crit. Rev. Biotechnol. 25, 113-152.

488 Muley, A.B., Ladole, M.R., Suprasanna, P., Dalvi, S.G., 2019. Intensification in 489 biological properties of chitosan after y-irradiation. Int. J. Biol. Macromol. 131, 435-444.

490 Nascimento, F.J.A., Bradshaw, C., 2016. Direct and indirect effects of ionizing radiation 491 on grazer-phytoplankton interactions. J. Environ. Radioact. 155-156, 63-70.

492 Padlyak, B.V., Kornatowski, J., Zadrozna, G., Rozwadowski, M., Gutsze, A., 2000. 493 Electron paramagnetic resonance spectroscopy of chromium in CrAPO-5 molecular 494 sieves. J. Phys. Chem. 104, 11837-11843.

495 Peisach, J., Blumberg, W.E., 1974. Structural implications derived from the analysis of 496 electron paramagnetic resonance spectra of natural and artificial copper proteins. Arch. 497 Biochem. Biophys. 165, 691-708.

498 Petrovič, A., Simonič, M., 2016. Removal of heavy metal ions from drinking water by 499 alginate-immobilised Chlorella sorokiniana. Int. J. Environ. Sci. Technol. 13, 1761-1780. 500 Rea, G., Esposito, D., Damasso, M., Serafini, A., Margonelli, A., Faraloni, C., Torzillo, 501 G., Zanini, A., Bertalan, I., Johanningmeier, U., Giardi, M.T., 2008. Ionizing radiation 502 impacts photochemical quantum yield and oxygen evolution activityof Photosystem II in 503 photosynthetic microorganisms. Int. J. Radiat. Biol. 84, 867-877.

504 Rivasseau, C., Farhi, E., Compagnon, E., de Gouvion Saint Cyr, D., van Lis, R., 505 Falconet, D., Kuntz, M., Atteia, A., Couté, A., 2016. Coccomyxa actinabiotis sp. nov. 506 (Trebouxiophyceae, Chlorophyta), a new green microalga living in the spent fuel cooling 507 pool of a nuclear reactor. J. Phycol. 52, 689-703. 
508 Russell, B., 1995. Determination of Factors Limiting Enzymatic Hydrolysis of the

509 Chlorella sorokiniana Cell Wall, PhD Dissertation. University of Florida, Gainesville.

510 Santier, S., Gilet, R., Malaise, E.P., 1985. Induced radiation resistance during low-dose-

511 rate y irradiation in plateau-phase Chlorella cells. Radiat. Res. 104, 224-233.

512 Sigel, A., Sigel, H., 2000. Metal lons in Biological Systems: Manganese and Its Role in

513 Biological Processes. Marcel Dekker, New York.

514 Simonović, J., Stevanić, J., Djikanović, D., Salmen, L., Radotić, K., 2011. Anisotropy of

515 cell wall polymers in branches of hardwood and softwood: a polarized FTIR study.

516 Cellulose 18, 1433-1440.

517 Sokołowska, M., Bal, W., 2005. Cu (II) complexation by "non-coordinating" N-2-

518 hydroxyethylpiperazine-N'-2-ethanesulfonic acid (HEPES buffer). J. Inorg. Biochem. 99, $519 \quad 1653-1660$.

520 Spasojević, I., Mojović, M., Blagojević, D., Spasić, S.D., Jones D.R., Nikolić-Kokić, A., 521 Spasić, M.B., 2009. Relevance of the capacity of phosphorylated fructose to scavenge 522 the hydroxyl radical. Carbohydr. Res. 344, 80-84.

523 UNSCEAR, 2011. Sources and Effects of Ionizing Radiation. United Nations, New York.

524 Vanhoudt, N., Vandenhove, H., Leys, N., Janssen, P., 2018. Potential of higher plants, 525 algae, and cyanobacteria for remediation of radioactively contaminated waters. 526 Chemosphere 207, 239-254.

527 Wasikiewicz, J.M., Yoshii, F., Nagasawa, N., Wach, R.A., Mitomo, H., 2005. 528 Degradation of chitosan and sodium alginate by gamma radiation, sonochemical and 529 ultraviolet methods. Radiat. Phys. Chem. 73, 287-295. 
530 Wilde, E.W., Benemann, J.R., 1993. Bioremoval of heavy metals by the use of

531 microalgae. Biotechnol. Adv. 11, 781-812.

532 Yap, B.J.J., Crawford, S.A., Dagastine, R.R., Scales, P.J., Martin, G.J.O., 2016.

533 Nitrogen deprivation of microalgae: effect on cell size, cell wall thickness, cell strength,

534 and resistance to mechanical disruption. J. Ind. Microbiol. Biotechnol. 43, 1671-1680.

535 Zegota, H., 2002. Some quantitative aspects of hydroxyl radical induced reactions in $y$ -

536 irradiated aqueous solution of pectins. Food Hydrocoll. 16, 353-361.

537 Zuppini, A., Andreoli, C., Baldan B., 2007. Heat stress: an inducer of programmed cell

538 death in Chlorella saccharophila. Plant Cell Physiol. 48, 1000-1009.

539 
541 Fig. 1. Representative TEM micrographs of $C$. sorokiniana cells and the analysis of cell

542 wall parameters. (a) Characteristic TEM micrographs - controls and cells exposed to

543 different doses of X-ray irradiation in the stationary phase. Analysis was performed one

544 day after the treatment. Cell wall structure shows two main layers: trilaminar sheath -

545 TLS (1) and fibrilar wall (2), see the enlarged area of the cell (dashed line box). (b) Data

546 on thickness of cell wall layers; (c) The yield of cell wall (mass per $\mathrm{g}$ of fresh weight

547 (FW). Mean control values (Ctrl) are presented as full line \pm SE (dashed line). Statistical 548 significance $-{ }^{*} p<0.05$.

549 Fig. 2. FTIR spectra of cell wall isolates from a C. sorokiniana stationary phase culture 550 that was untreated (control) or irradiated (2 Gy, similar spectra were recorded for 5 Gy). 551 Circles mark the areas of interest.

552 Fig. 3. EPR spectra of DEPMPO spin-adduct with $\mathrm{HO}$ that are produced in the absence 553 or the presence of cell wall isolates. (a) Fenton reaction: $\mathrm{Fe}^{2+}(1 \mathrm{mM})+\mathrm{H}_{2} \mathrm{O}_{2}(3 \mathrm{mM})$.

554 Full circle - the amplitude of this peak was used to calculate antioxidative capacity. (b) 555 Cell wall of untreated algae (controls); (c) Cell wall of algae exposed to 1 Gy; (d) Cell 556 wall of algae exposed to $2 \mathrm{~Gy}$; (e) Cell wall of algae exposed to 5 Gy. Antioxidative 557 capacity is presented as mean \pm SE. * - statistically significant compared to Fenton 558 reaction $(p<0.05)$.

559 Fig. 4. The capacity of C. sorokiniana cell wall isolates to bind metal ions. (a) $\mathrm{Cu}^{2+}$ 560 binding capacity of cell wall polymers from untreated and irradiated microalgae. (b) $\mathrm{Mn}^{2+}$ 561 binding capacity. (c) $\mathrm{Cr}^{3+}$ binding capacity. Results are presented as means \pm SE. Mean 
562 control values (Ctrl) are presented as full line \pm SE (dashed line). * - statistical 563 significance compared to non-irradiated culture $(p<0.05)$.

564 Fig. 5. $77 \mathrm{~K}$ EPR spectra of $\mathrm{Cu}^{2+}$. (a) $\mathrm{Cu}^{2+}(1.5 \mathrm{mM})$ in Hepes buffer $(20 \mathrm{mM}$; pH 7.5);

565 (b) $\mathrm{Cu}^{2+}+$ cell wall isolates from control and irradiated microalgae in the buffer. (c) $\mathrm{Cu}^{2+}$ $566+$ chitosan. Recording parameters were: power attenuation, $25 \mathrm{~dB}$; modulation 567 amplitude, $0.8 \mathrm{mT}$; number of scans/accumulations, 10. Gray lines - simulations that 568 delivered the presented $g$ and $A$ values.

569 Fig. 6. $77 \mathrm{~K}$ EPR spectra of $\mathrm{Mn}^{2+}$ and $\mathrm{Cr}^{3+}$. (a) $\mathrm{Mn}^{2+}(1.5 \mathrm{mM})$ in Hepes buffer $(20 \mathrm{mM}$; $570 \mathrm{pH}$ 7.5); (b) Cell wall isolates (from control and irradiated microalgae) that were 571 incubated with $\mathrm{Mn}^{2+}$ and placed into the buffer. (c) $\mathrm{Cr}^{3+}(1.5 \mathrm{mM})$ in Hepes buffer $(20$ $572 \mathrm{mM} ; \mathrm{pH}$ 7.5). Arrowheads mark 4 lines of $\mathrm{Cr}^{3+}$ with $I=3 / 2$. (d) Cell wall isolates (from 573 control and irradiated microalgae) that were incubated with $\mathrm{Cr}^{3+}$ and placed into the 574 buffer. Recording parameters were: power attenuation, $25 \mathrm{~dB}$; modulation amplitude, $5750.8 \mathrm{mT}$; number of scans, 10. 

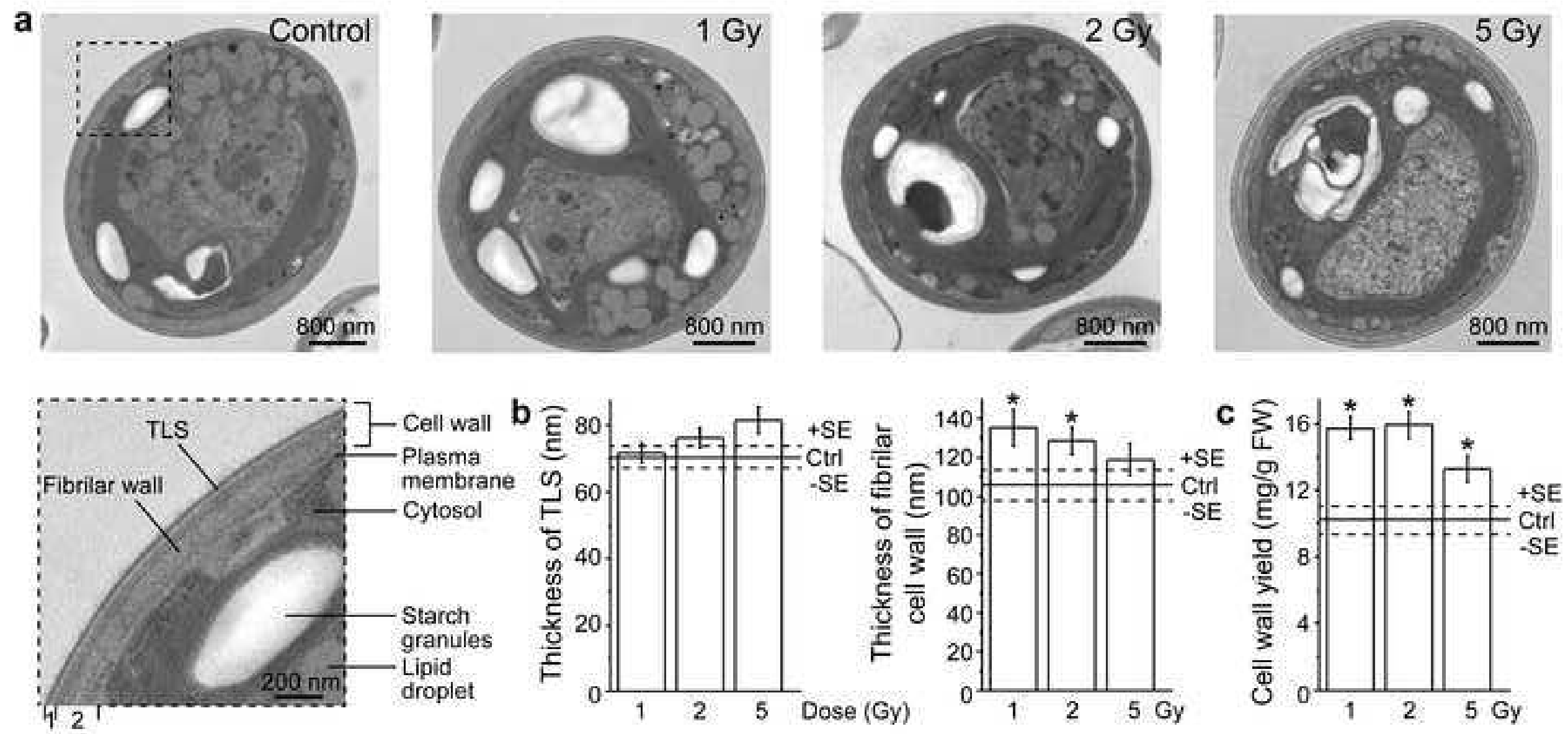

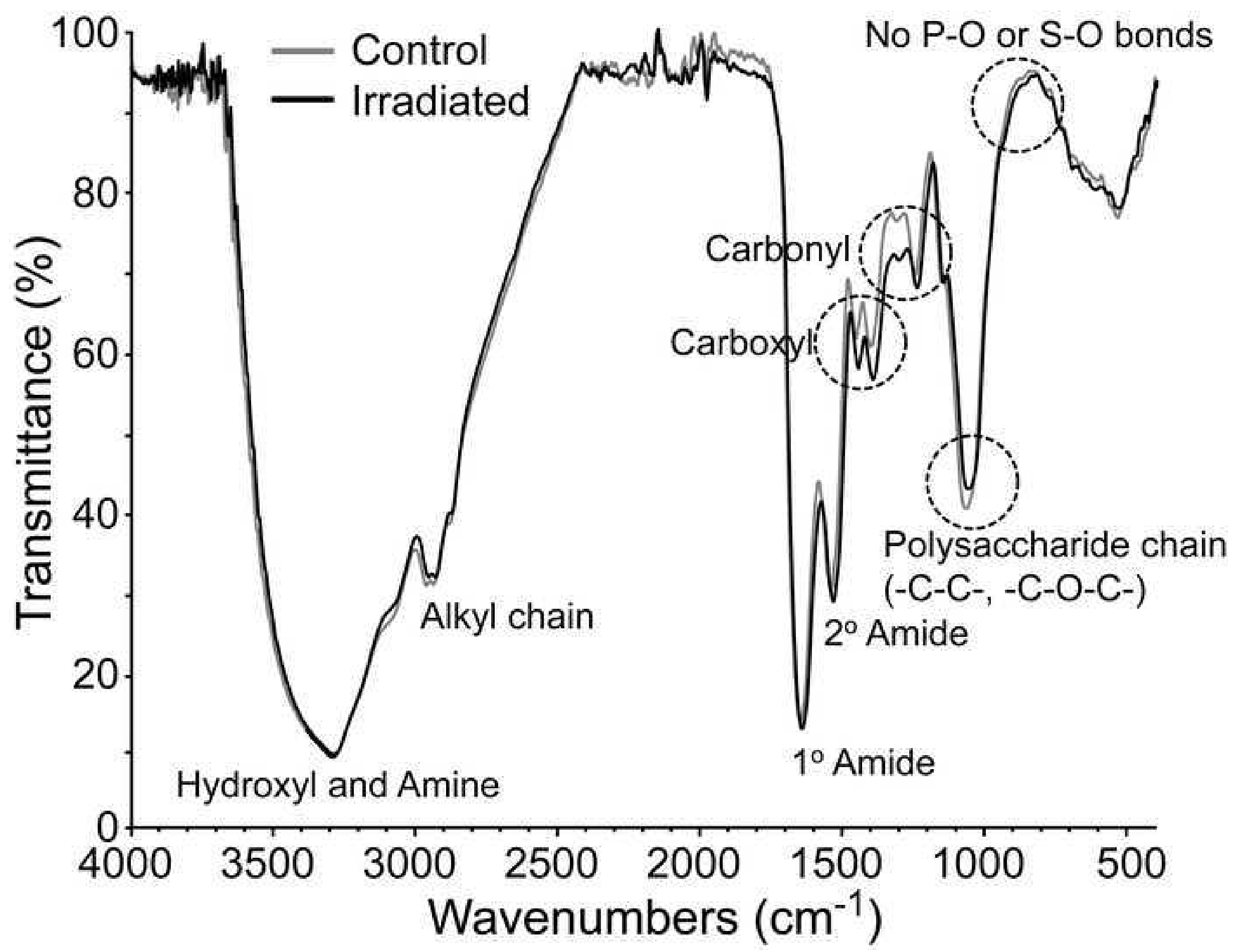


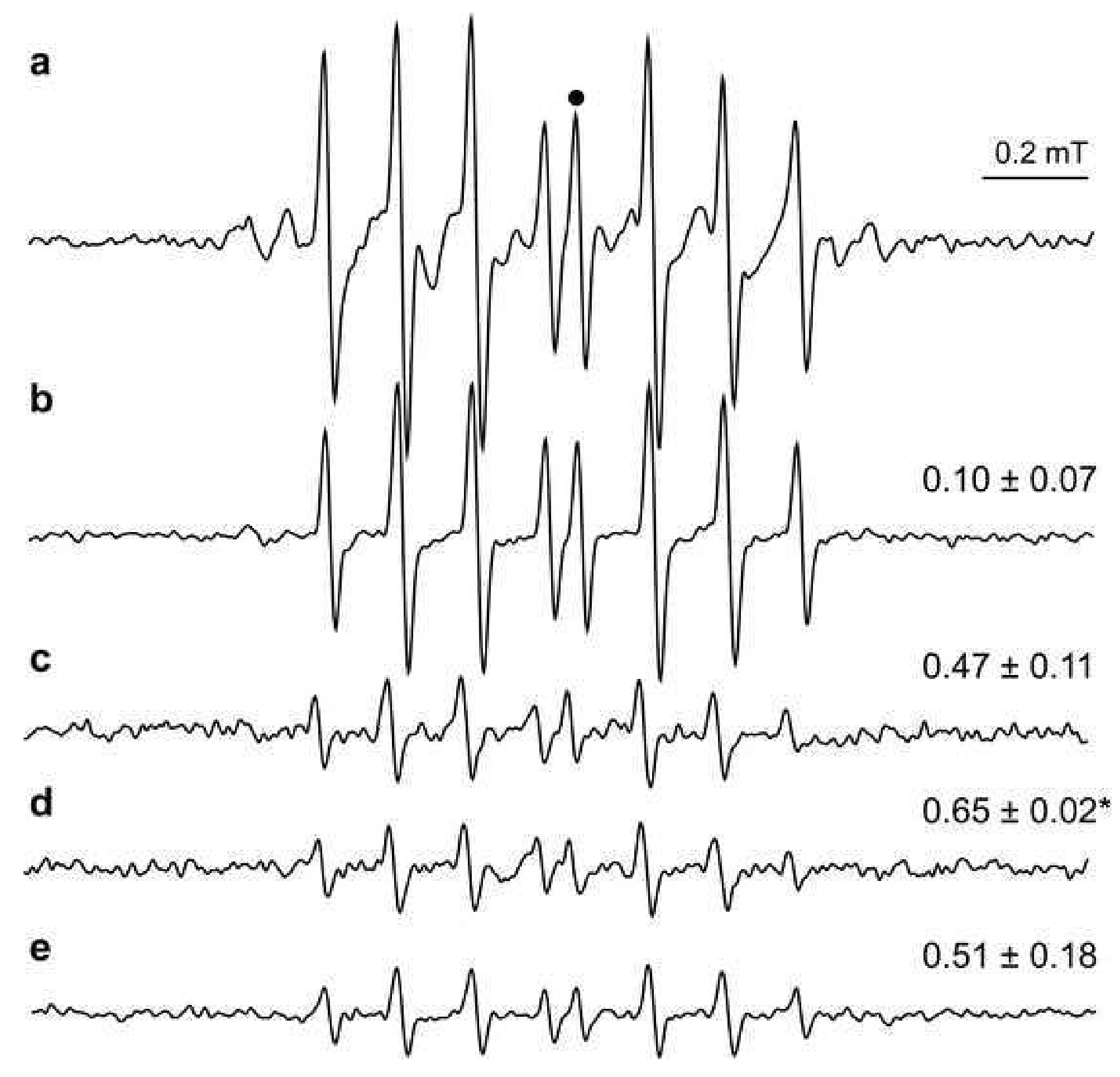



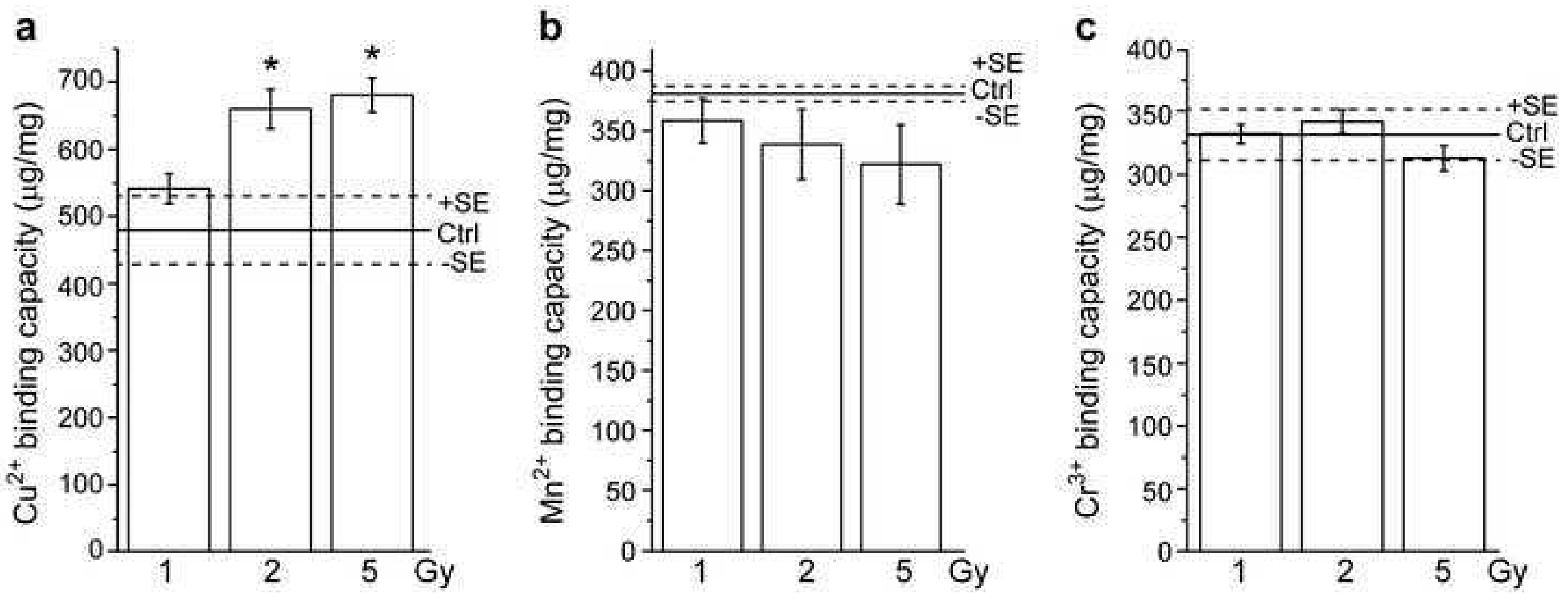
a $\quad A_{11}=14.7 \mathrm{mT}$

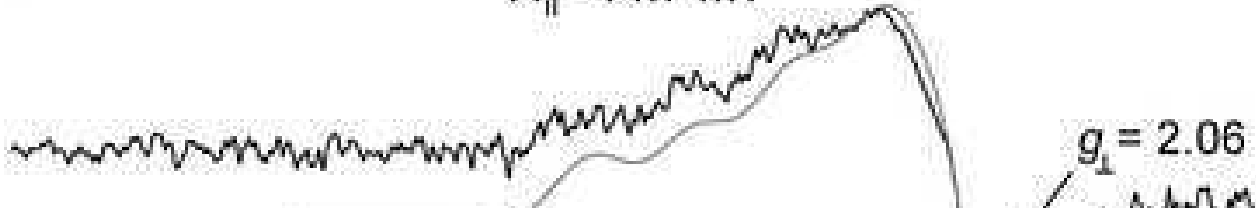

b

b

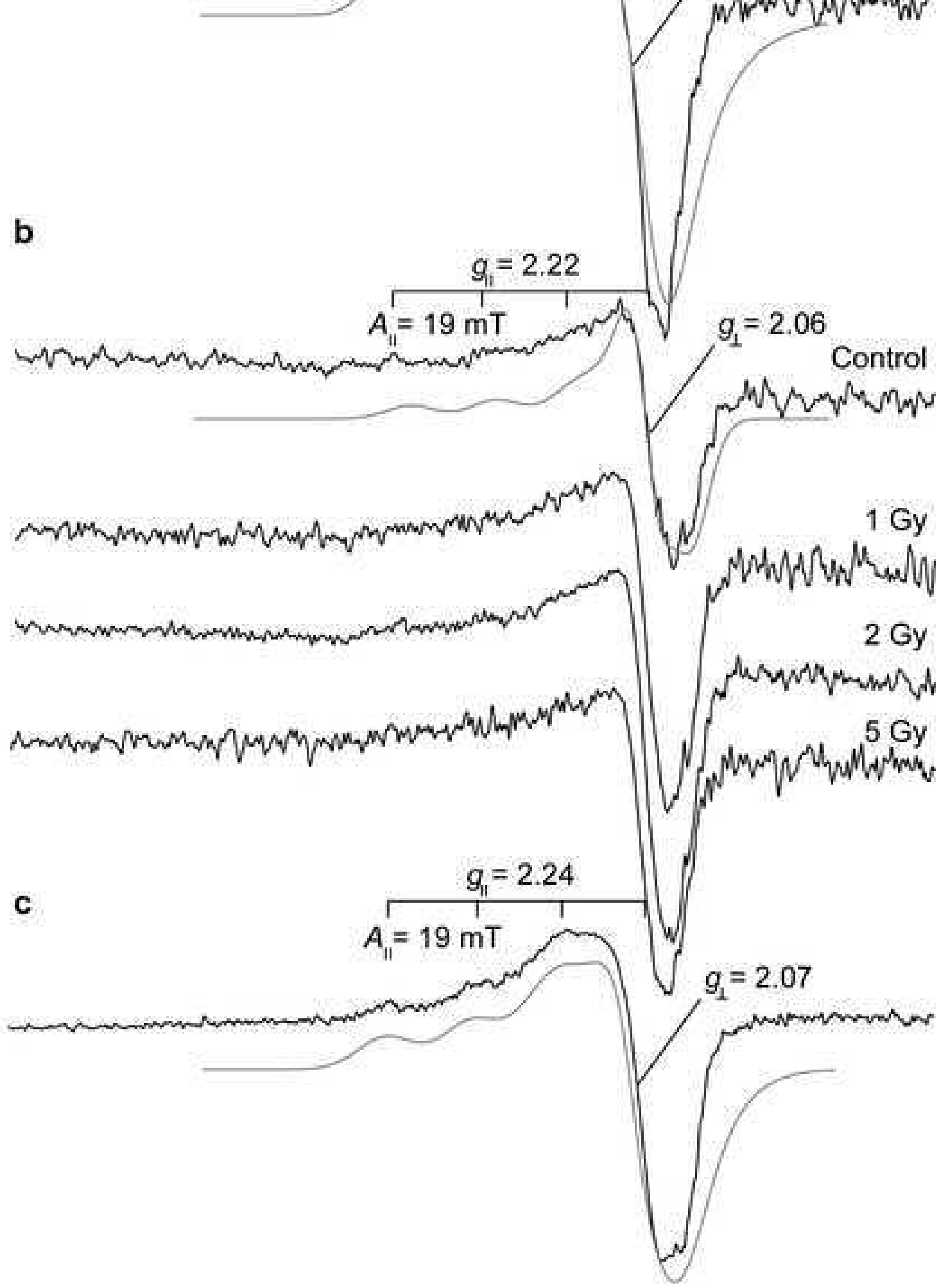

$\begin{array}{llllllllll}200 & 220 & 240 & 260 & 280 & 300 & 320 & 340 & 360 & 380\end{array}$ Field $(\mathrm{mT})$ 
Figure 6

Click here to access/download;Figure;Fig6.tif $\underline{\underline{\boldsymbol{}}}$

a

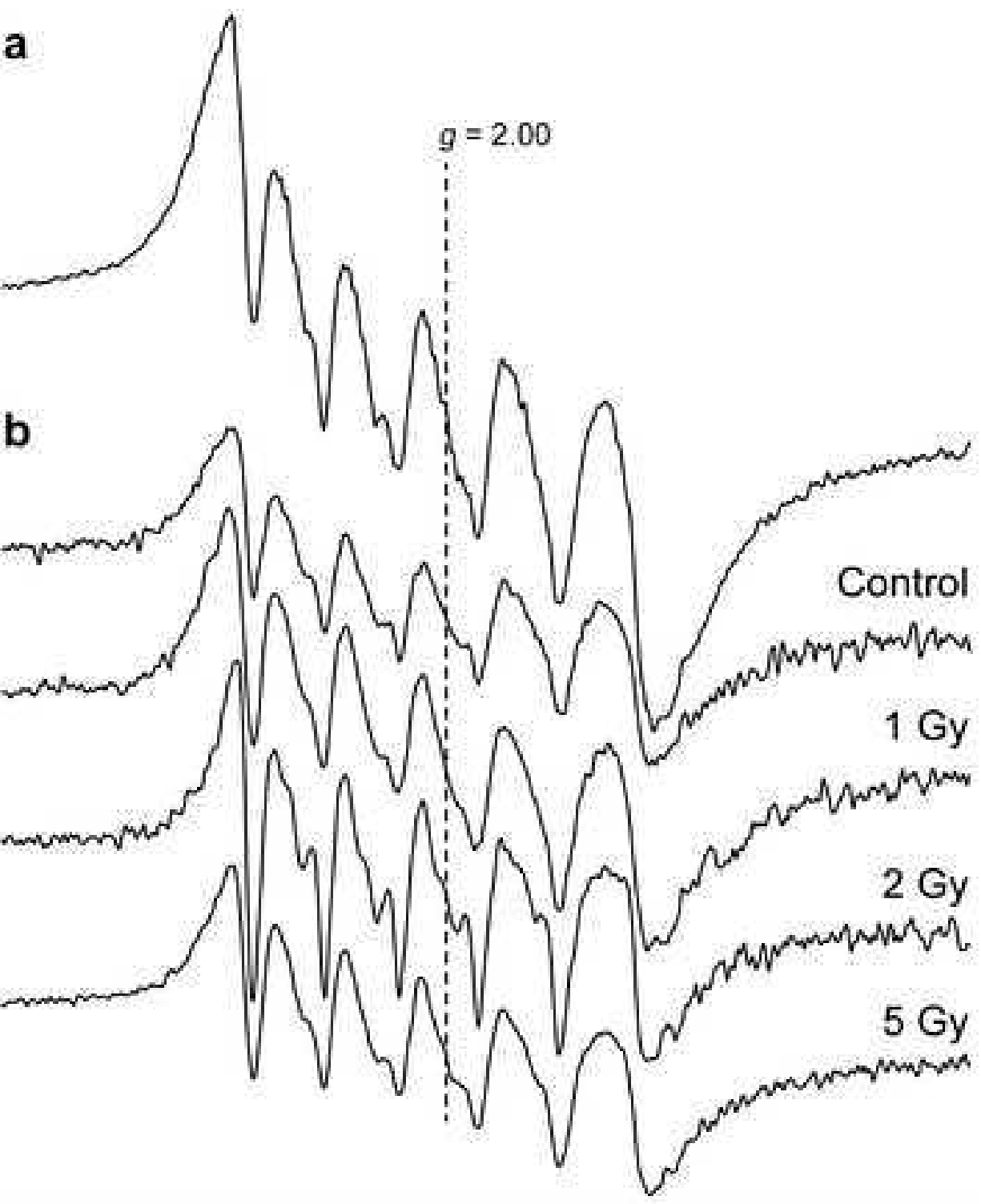

C

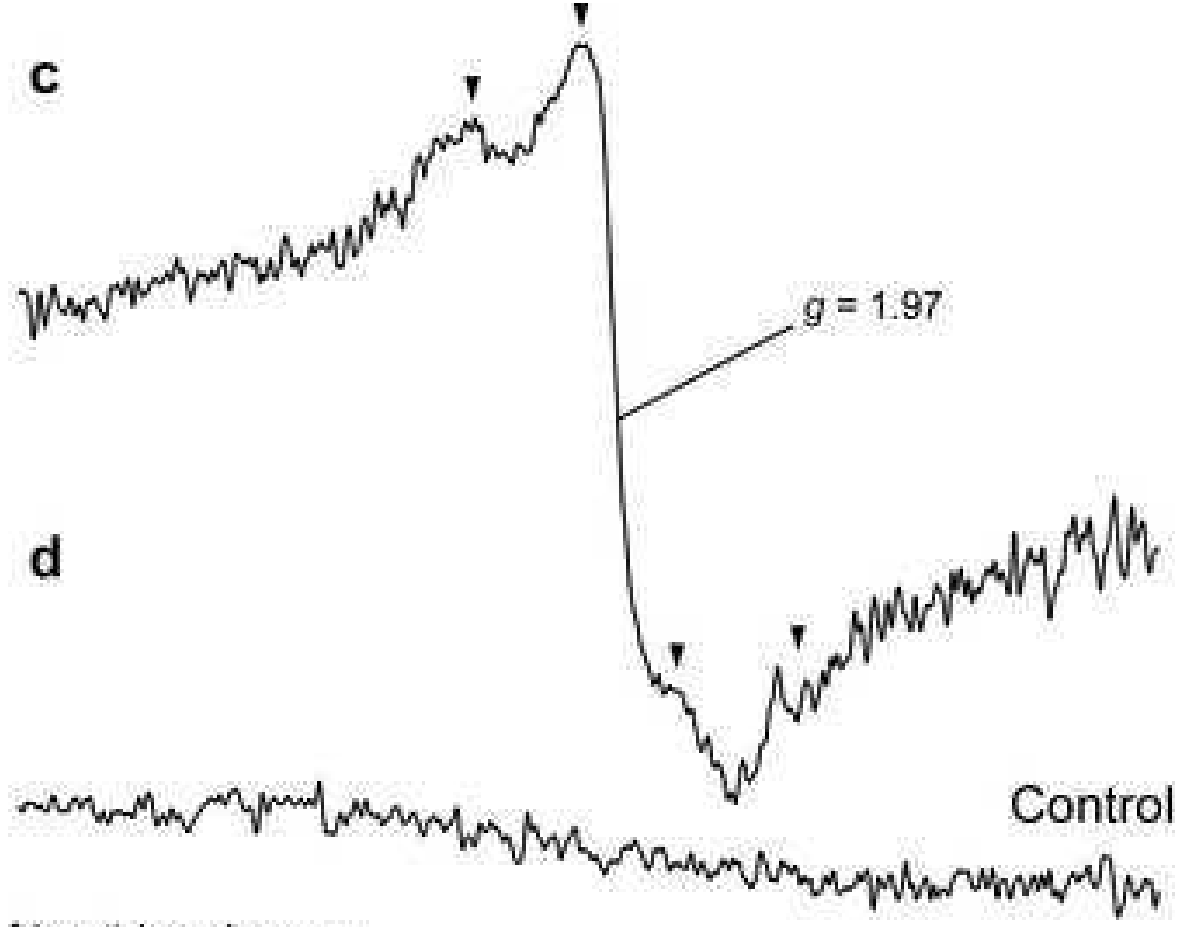
PGP

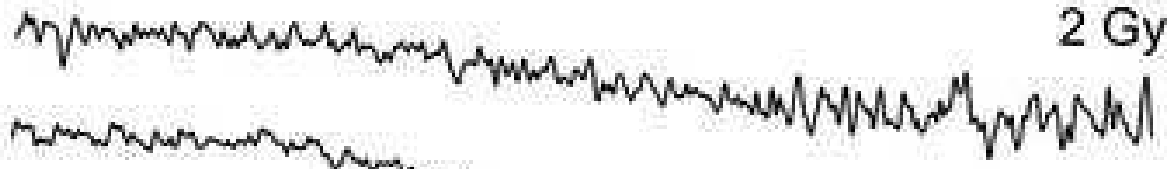
$5 \mathrm{~Gy}$

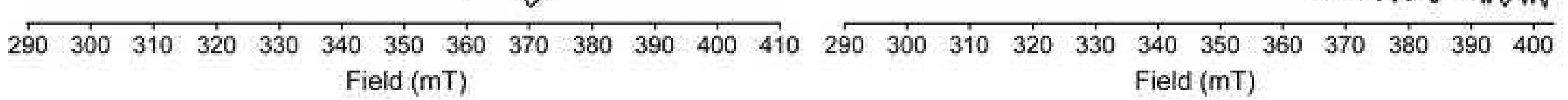

